Piotr Fiedorczyk

\title{
Z badań nad prawem rodzinnym w projekcie kodeksu cywilnego z 1948 r.
}

\begin{abstract}
Summary
In February 1947 the Codification Commission was established. The Commission was to prepare the version of Civil Code, based on the existing acts and decrees. The changes in the existing law could be done only exceptionally. There were two persons nominated to prepare the draft of family law as a part of civil code. Jan Witecki and Seweryn Szer prepared the draft in 15 months, so the first reading was concluded in August 1948. The Commission has modified the configuration of proposed draft, which was based on French and Swiss civil laws. There were some important changes in marital law done. The most important of them were connected with the separation - the consequences of separation were regulated. There were important changes in the construction of divorce proposed. The draft was on a good level of legal regulation. In 1949 the works on new code were stopped because of political reasons. The draft was described as "bourgeois" and did not fit to process of stalinisation of Poland.
\end{abstract}

\section{Wprowadzenie}

Prace nad kodeksem cywilnym rozpoczęły się w lutym 1947 r., kiedy minister sprawiedliwości Henryk Świątkowski powołał pięcioosobową Komisję Kodyfikacyjną Prawa Cywilnego. W skład komisji wchodzili: Jan Wasilkowski, Seweryn Szer, Jan Witecki, Aleksander Wolter i Jan Lisiewski. Sekretarzem komisji mianowano Witolda Czachórskiego, wówczas sędziego Sądu Grodzkiego w Gliwicach, delegowanego do Departamentu Ustawodawczego Ministerstwa 
Sprawiedliwości ${ }^{1}$. Na pierwszym posiedzeniu w dniu 25 marca 1947 r. komisja uchwaliła regulamin oraz określiła zakres treści i układ systematyczny przyszłego kodeksu. Wyznaczyła też referentów i koreferentów projektu. W odniesieniu do prawa rodzinnego zostali nimi J. Witecki i S. Szer². Niniejszy tekst przedstawia przebieg prac nad księgą II kodeksu, zawierającą prawo rodzinne oraz omawia rozwiązania przyjęte $\mathrm{w}$ pierwszym czytaniu projektu $\mathrm{w}$ zakresie prawa małżeńskiego.

\section{Przebieg prac nad projektem prawa rodzinnego}

Należy przyjąć, że ustalony na pierwszym posiedzeniu komisji układ przyszłego kodeksu wpływał na kolejność prac nad poszczególnymi księgami projektu. Było więc rzeczą naturalną, że najpierw zajęto się treścią części ogólnej. $\mathrm{W}$ pracach nad tą księgą pojawiała się trudność, niespotykana w przypadku pozostałych części kodeksu. Polegała ona na tym, że podstawą prac nie mógł w tym przypadku być wyłącznie dekret unifikacyjny, gdyż przepisy z zakresu części ogólnej znajdowały się przede wszystkim w kodeksie zobowiązań z 1933 r. Zadanie legislatorów polegało więc na stworzeniu całkowicie nowej księgi - ale w oparciu o istniejące przepisy. Przyjąć należy, że było to zadanie bardziej skomplikowane niż w wypadku innych ksiąg kodeksu. Projekt został opracowany przez Jana Wasilkowskiego jako referenta oraz Aleksandra Woltera jako koreferenta. Był przedmiotem pierwszego czytania w dniach 4-10 listopada 1947 r. Został wówczas uchwalony, następnie wyłoniony przez komisję trzyosobowy komitet redakcyjny ustalił ostateczny tekst, który 19 listopada 1947 r. został przyjęty jako tekst pierwszego czytania ${ }^{3}$.

Konieczność odnotowania prac nad częścią ogólną wynika z dwóch przyczyn. Przebieg wskazuje na to, że stosowano ustalenia wynikające z regulaminu prac. Ciekawym rozwiązaniem było powierzenie redakcji tekstu pierwszego czytania jednej z osób spoza grona referentów ${ }^{4}$. Zdecydowanie ważniejsze są natomiast rozwiązania merytoryczne projektu części ogólnej, gdyż miały one wpływ

\footnotetext{
${ }^{2}$ Powyższe zagadnienia omawiam szerzej w: P. Fiedorczyk, O początkach prac nad kodyfikacją polskiego prawa cywilnego w 1947 r., „Miscellanea historico-iuridica” 2006, t. 4, s. 109-120.

${ }^{3}$ Projekt części ogólnej kodeksu cywilnego, op. cit., s. 19.

${ }^{4} \mathrm{~W}$ skład komisji redakcyjnej miał wchodzić sekretarz i dwóch członków komisji ( $\$ 11$ regulami$\mathrm{nu}$ ). Tekst regulaminu zob. P. Fiedorczyk, Dokumenty archiwalne dotyczace organizacji prac nad unifikacja i kodyfikacja polskiego prawa cywilnego w latach 1945-1948, „Miscellanea historio-iuridica” 2006, t. 4 , s. 167-169.
}

${ }^{1}$ Projekt cześci ogólnej kodeksu cywilnego, „Demokratyczny Przegląd Prawniczy” 1947, nr 12, s. 19. 
na decyzje podejmowane $\mathrm{w}$ pracach nad prawem rodzinnym. Należy przede wszystkim zauważyć, że projekt nie zawierał norm prawa opiekuńczego, co prawdopodobnie oznaczało, że wzorem niemieckim ta część prawa cywilnego zostanie włączona do księgi regulującej prawo rodzinne. Technicznie możliwe było także rozwiązanie polegające na wydzieleniu prawa opiekuńczego w odrębną księgę. Ponadto część postanowień zawartych w projekcie odnosiła się bezpośrednio do prawa rodzinnego. Wśród nich najważniejsze są normy dotyczące pełnoletniości (uzyskiwanej z chwilą ukończenia 18. roku życia - art. $10 \$ 1$ ). Jednocześnie postanowiono, że małoletni od zawarcia związku małżeńskiego jest uważany za pełnoletniego - art. $10 \$ 2$. Projektowany art. 15 przewidywał z kolei, że małżonkowie mogą mieć osobne miejsca zamieszkania, natomiast miejsce zamieszkania małoletnich dzieci związane jest $\mathrm{z}$ miejscem zamieszkania rodziców lub tego z rodziców, który sprawuje władzę rodzicielską. W przypadku, gdy władzę rodzicielską sprawowali oboje rodzice, mający osobne miejsca zamieszkania, miejscem zamieszkania dziecka miało być miejsce zamieszkania tego z rodziców, u którego dziecko stale przebywa (art. 16 \$2). Podobne normy odnosiły się do osoby pozostającej pod opieką (art. 17) oraz przysposobionej (art. 18) .

Prace nad prawem rodzinnym w projektowanym kodeksie cywilnym przebiegały zgodnie z przyjętym regulaminem oraz ustaleniami zapadłymi na pierwszym posiedzeniu komisji i nie były skomplikowane. Referent tej części kodeksu Jan Witecki opracował projekt księgi II, obejmującej prawo małżeńskie osobowe, prawo małżeńskie majątkowe oraz prawo o stosunkach rodziców i dzieci. Księga ta liczyła 250 artykułów ${ }^{6}$. Równocześnie powstał projekt księgi III, obejmującej prawo opiekuńcze, składającej się z 89 artykułów ${ }^{7}$. Warto zauważyć, że referent wstępnie wyodrębnił prawo opiekuńcze $\mathrm{w}$ oddzielną księgę, co oczywiście nie przesądzało ostatecznego układu przepisów. Przyjęta przez referenta systematyka przepisów powielała układ dekretów unifikacyjnych, przy czym autor powrócił do tradycyjnej nazwy „Rodzice i dzieci”, określającej treść dekretu prawo rodzinne. Rozwiązanie takie wynikało zapewne $\mathrm{z}$ faktu zarezerwowania terminu „prawo rodzinne” jako nazwy dla całej księgi. Referent przyjął założenie, że przy opracowaniu projektu będzie „starał się wprowadzić jak najmniej zmian do obowiązującego prawa" ${ }^{8}$. Opracowany w ten sposób projekt był gotowy jesienią 1947 r. i został wtedy przekazany koreferentowi Sewerynowi

\footnotetext{
${ }^{5}$ Wszystkie przepisy cytuję za: Projekt części ogólnej kodeksu cywilnego, op. cit., s. 19-24.

${ }^{6}$ Ksiega 2. Prawo rodzinne. I projekt, AAN MS 2231, k. 25-96.

${ }^{7}$ Księga 3. Opieka i kuratela. I projekt referentów, AAN MS 2232, k. 18-35.

${ }^{8}$ Protokół posiedzenia Komisji Kodyfikacyjnej Prawa Cywilnego w dniu 17 II 1948 r., AAN MS 2380,
} k. 1 . 
Szerowi. Uwagi zgłoszone przezeń w siedmiostronicowym piśmie z 27 listopada 1947 r. ${ }^{9}$ były bardzo szczegółowe. Wskazywały na to, że koreferent nie miał uwag do generalnych rozwiązań. Proponował natomiast 56 poprawek, w dużej części o charakterze terminologicznym. Poprawki te zostały generalnie zaakceptowane przez J. Witeckiego ${ }^{10}$, a opracowany $\mathrm{w}$ ten sposób projekt prawa rodzinnego przekazano pozostałym członkom komisji.

Pierwsze czytanie projektu przeprowadzano w następującej kolejności. Najpierw, w dniach 17, 20, 21, 23, 24, 25 lutego 1948 r., odbyło się pierwsze czytanie przepisów dotyczących osobowego prawa małżeńskiego ${ }^{11}$. Prace zakończyły się powierzeniem redakcji uchwalonego tekstu S. Szerowi, A. Wolterowi i W. Czachórskiemu ${ }^{12}$. Zatwierdzenie redakcji miało miejsce $\mathrm{w}$ dniach 2-5 kwietnia 1948 r. $^{13}$ Po opracowaniu osobowego prawa małżeńskiego przystąpiono natychmiast do prac nad majątkowymi ustrojami małżeńskimi, skoro pierwsze czytanie odbyło się w dniach 5, 21, 22, 23, 24 kwietnia $^{14}$. Warto zwrócić uwagę, że $\mathrm{w}$ tym przypadku podstawą prac był poważnie w międzyczasie zmodyfikowany projekt J. Witeckiego ${ }^{15}$. Nie można już dziś odtworzyć przyczyn dokonanych zmian ani okoliczności towarzyszących ich wprowadzeniu; przyjąć należy, że były akceptowane przez referentów, skoro J. Witecki sam wnosił o prowadzenie prac nad zmodyfikowanym tekstem. Ostateczną redakcję uchwalonego projektu powierzono J. Wasilkowskiemu ${ }^{16}$. Została ona zatwierdzona na posiedzeniu komisji w dniach 28-30 maja 1948 roku $^{17}$, przy czym w większej części tego posiedzenia nie uczestniczyli referenci projektu. Następnym działem prawa rodzinnego opracowanym w pierwszym czytaniu były przepisy o pokrewieństwie i powinowactwie. Komisja zajmowała się nimi w dniach 31 maja, 1, 3, 4, 5, 7 czerwca $1948 \mathrm{r}^{18}$ Prace nad tym działem

${ }^{9}$ Pismo S. Szera do J. Witeckiego z 27 listopada 1947 r., AAN MS 2231, k. 17-24.

${ }^{10}$ Pismo J. Witeckiego do S. Szera $z 18$ grudnia 1947 r., AAN MS 2231, k. 16.

${ }^{11}$ Protokót posiedzenia Komisji Kodyfikacyjnej Prawa Cywilnego w dniu 17 II 1948 r., AAN MS 2380, k. 1-59.

${ }^{12}$ Ibidem, k. 59. Należy zwrócić uwage na niezgodność danych zamieszczonych na ten temat w „Demokratycznym Przeglądzie Prawniczym”. Podano w nim, że pierwsze czytanie miało miejsce w dniach 19-25 lutego 1948 r., a redakcję tekstu powierzono Janowi Wasilkowskiemu. Zob. Projekt księgi drugiej kodeksu cywilnego, „Demokratyczny Przegląd Prawniczy” 1948, nr 4, s. 8.

${ }^{13}$ Ibidem, s. 8.

${ }^{14}$ Protokót posiedzenia Komisji Kodyfikacyjnej Prawa Cywilnego $w$ dn. 5, 21, 22, 23, 24 IV 1948 r., AAN MS 2380, k. 60-98.

${ }^{15}$ Projekt był oznaczony datą , 5 kwietnia 1948”. Ibidem, k. 60.

${ }^{16}$ Projekt księgi drugiej kodeksu cywilnego, „Demokratyczny Przegląd Prawniczy” 1948, nr 6, s. 10.

${ }^{17}$ Protokół posiedzenia Komisji Kodyfikacji Prawa Cywilnego w dniach 28-30/V 1948 r., AAN MS 2380, k. 99-118.

${ }^{18}$ Protokót posiedzenia Kodyfikacji Prawa Cywilnego w dniach 31 V 1948 r. - 7 VI 1948 r., AAN MS 2380, k. 119-177. 
zajęły najwięcej czasu, co wydaje się zrozumiałe, gdyż był on najbardziej obszerny. Redakcję powierzono ponownie J. Wasilkowskiemu ${ }^{19}$. Została ona przyjęta na wyjazdowym posiedzeniu komisji w Szklarskiej Porębie ${ }^{20} \mathrm{w}$ dniach 3-4 sierpnia 1948 r. $^{21}$ Również w Szklarskiej Porębie odbyło się pierwsze czytanie prawa o opiece i kurateli. Najpierw w dniach 5 i 6 sierpnia uchwalono projekt $\mathrm{w}$ pierwszym czytaniu, powierzając redakcję J. Wasilkowskiemu ${ }^{22}$, następnie w dniu 17 sierpnia przyjęto ostateczną redakcję ${ }^{23}$. W ten sposób po półtora rocznym okresie od rozpoczęcia prac opracowano projekt prawa rodzinnego w pierwszym czytaniu. Warto podkreślić, że ustalenie tekstu projektu odbywało się z udziałem ministra H. Świątkowskiego, który uczestniczył w dużej części posiedzeń. Przebieg prac unaocznił także, jak dużą rolę odgrywał w nich Jan Wasilkowski. Powierzono mu bowiem (nie w pełni zgodnie z regulaminem prac) redakcję wszystkich przyjmowanych przez komisję projektów. Oznaczało to w praktyce, że stał się koordynatorem prac, spełniając ponadto funkcję osoby odpowiedzialnej za spójność oraz niesprzeczność projektu.

Opracowane w ten sposób projekty prawa rodzinnego i prawa opiekuńczego zostały ostatecznie umieszczone w jednej księdze kodeksu pod nazwą Prawo rodzinne i opiekuńcze. Zmiana w stosunku do stanu wytworzonego dekretami unifikacyjnymi miała polegać na tym, że termin „prawo rodzinne” miał odtąd obejmowaćnietylko stosunkiprawnemiędzyrodzicamiadziećmi (pokrewieństwo i powinowactwo), lecz całość prawa, określanego niegdyś mianem "familijnego"24. Podkreślić należy, że decyzja o włączeniu prawa opiekuńczego do księgi II zapadła dopiero w ostatnim etapie prac redakcyjnych w dniu 17 sierpnia 1948 roku. „Prof. Wasilkowski zgłasza wniosek o włączenie prawa opiekuńczego, jako tytułu III do księgi drugiej kodeksu, która powinna mieć tytuł: Prawo rodzinne i opiekuńcze. Po dyskusji zgodnie przyjęto ten wniosek" - stwierdza lakonicznie protokół ${ }^{25}$. Wydaje się, że wspomniana decyzja zapadła jeszcze przed jej

${ }^{19}$ Projekt ksiegi drugiej kodeksu cywilnego, „Demokratyczny Przegląd Prawniczy” 1948, nr 8, s. 3.

${ }^{20} \mathrm{~W}$ zespole archiwalnym Ministerstwa Sprawiedliwości zachował się dokument, w świetle którego dyrektor S. Szer zwracał się do min. H. Świątkowskiego z prośbą o wyasygnowanie kwoty $31500 \mathrm{zł}$ na pokrycie kosztów pobytu sześciu członków komisji w Szklarskiej Porębie w ministerialnym ośrodku wypoczynkowym „Słoneczna” w dn. 2-22 sierpnia 1948 r. Prawdopodobnie dążono w ten sposób do przyśpieszenia prac nad kodeksem. Zob. AAN MS 2390, k. 112.

${ }^{21}$ Protokót posiedzenia Komisji Kodyfikacji Prawa Cywilnego w dniach 3-4/ VIII 48 r., w Szklarskiej Porębie, AAN MS 2380, k. 185-211.

${ }^{22}$ Projekt księgi drugiej kodeksu cywilnego, „Demokratyczny Przegląd Prawniczy” 1948, nr 9, s. 15.

${ }^{23}$ Protokót posiedzenia Komisji Kodyfikacji Prawa Cywilnego. Szklarska Poręba, dnia 17 VIII 1948 r., AAN MS 2381, k. 75-84.

${ }^{24}$ S. Szer, Projekt kodeksu cywilnego. Małżeństwo, „Demokratyczny Przegląd Prawniczy” 1948, nr 6, s. 3.

${ }^{25}$ Protokół z posiedzenia, doc. cit., AAN MS 2381, k. 75. 
formalnym podjęciem. Była ona bowiem przesądzona, skoro nie zdecydowano się na umieszczenie prawa opiekuńczego w części ogólnej kodeksu.

Projektowana księga II kodeksu liczyła 309 artykułów i była podzielona, podobnie jak szwajcarski kodeks cywilny, na trzy tytuły: prawo małżeńskie, pokrewieństwo i powinowactwo, opieka i kuratela. Istotnejzmiany systematycznej dokonano w tytule I. Projekt nie wyodrębniał określonej grupy przepisów pod nazwą prawo małżeńskie majątkowe, jak czynił to dekret unifikacyjny z $1946 \mathrm{r}$. Włączył je natomiast do ogólnego tytułu „prawo małżeńskie”, który obejmował zarówno prawo małżeńskie osobowe, jak i majątkowe. Dotychczasowe przepisy dekretowe zostały wskutek tego rozłączone poprzez umieszczenie części z nich w dziale I „Małżeństwo”, z pozostałych zaś utworzono odrębny dział prawa małżeńskiego, regulujący tylko ustroje majątkowe. Propozycję tej zmiany zgłosił J. Wasilkowski, uzasadniając ją stwierdzeniem o sztucznym charakterze podziału na prawo małżeńskie osobowe i majątkowe. Pogląd ten zaakceptowali wszyscy członkowie komisji ${ }^{26}$. Nowe usystematyzowanie materii ustawowej było więc usprawiedliwiane okolicznością, że niepodobna jest, jak twierdził jeden z członków Komisji, dokonać iudicium finium regundorum między małżeńskimi prawami i obowiązkami natury majątkowej i niemajątkowej. Niemożność takiego ścisłego rozdzielenia spowodowała umieszczenie tych przepisów wspólnie $\mathrm{w}$ jednym $\mathrm{z}$ rozdziałów. Konsekwencją tego zabiegu stało się utworzenie działu regulującego wyłącznie małżeńskie ustroje majątkowe. Recypowano w ten sposób rozwiązania kodeksu szwajcarskiego (podobnie przepisy te skonstruowano w Kodeksie Napoleona), a odrzucono wcześniej stosowane rozwiązanie pochodzące z BGB i oparte na konstrukcji wyodrębnionego małżeńskiego prawa majątkowego ${ }^{27}$. Zastosowany podział oznaczał więc, że materia prawna, dotychczas regulowana czteroma dekretami, została zamieszczona w trzech tytułach jednej księgi - co wynikało z odrzucenia konstrukcji małżeńskiego prawa majątkowe$\mathrm{go}^{28}$. Omówione zmiany systematyki nie były jedynymi w tym zakresie, pozostałe dotyczyły niższych stopni systematycznej drabiny, wobec czego ich znaczenie jest mniejsze. Będą one omówione w innych miejscach, przy przedstawianiu poszczególnych tytułów księgi drugiej projektu.

${ }^{26}$ Protokół posiedzenia Komisji Kodyfikacyjnej Prawa Cywilnego w dn. 21 II 48 r., AAN MS 2380, k. 26.

${ }^{27}$ S. Szer, op. cit., s. 3.

${ }^{28}$ Warto zauważyć, że rozwiązanie zastosowane w projekcie recypował ostatnio współczesny polski ustawodawca. Nowelizacja k.r.o. z 2004 r. doprowadziła do wyodrębnienia przepisów o małżeńskich ustrojach majątkowych i połączenia majątkowych i niemajątkowych praw i obowiązków małżeńskich w jeden rozdział. 


\section{Prawo małżeńskie}

Zastosowana $\mathrm{w}$ projekcie systematyka przepisów $\mathrm{w}$ zakresie prawa małżeńskiego osobowego częściowo różniła się od przyjętej w dotychczas obowiązującym dekrecie. Porządek regulacji w dekrecie przedstawiał się następująco: zaręczyny, zawarcie związku małżeńskiego, prawa i obowiązki małżonków, unieważnienie, rozwód. W projekcie natomiast - zawarcie małżeństwa (art. 135-153), unieważnienie małżeństwa (art. 154-170), prawa i obowiązki małżonków (art. 171-182), rozwód (art. 183-196), stosunek do przepisów wyznaniowych (art. 197-198), zaręczyny (art. 199-202). Najważniejsza zmiana polegała na umieszczeniu przepisów o unieważnieniu po rozdziale o zawarciu małżeństwa. Uznano bowiem, że te dwie grupy przepisów ściśle się ze sobą wiążą, skoro unieważnienie jest spowodowane niezastosowaniem się do pewnych nakazów, stanowiących przesłanki ważności małżeństwa. Podkreślano, że przepisy o zawarciu i unieważnieniu małżeństwa stanowią logiczną całość ${ }^{29}$. Twierdzeniom tym nie można odmówić racji, ale wydaje się, że twórcy projektu prezentowali w ten sposób „techniczne” podejście do instytucji zawarcia małżeństwa. Bardziej przemawia układ, w którym prawa i obowiązki wynikają z zawarcia małżeństwa. Pamiętać także należy, że unieważnienie małżeństwa jest skutkiem pewnej patologii, nie zdarza się często, będąc raczej wyjątkiem. $\mathrm{Z}$ tych powodów umiejscowienie przepisów o unieważnieniu zostało ocenione negatywnie $\mathrm{w}$ trakcie dyskusji nad projektem ${ }^{30}$.

Podobnie oceniano umieszczenie regulacji zaręczyn na końcu tytułu o prawie małżeńskim. Twórcy projektu wyjaśniali, że instytucja zaręczyn ma charakter bardziej obyczajowy niż prawny. Prawo małżeńskie zajmuje się zaręczynami jedynie ubocznie, z konieczności, gdyż niektórych problemów majątkowych, mogących wyniknąć z zaręczyn, nie można rozstrzygać na podstawie prawa zobowiązaniowego (umowa przedwstępna), lecz należy je unormować w sposób odrębny. Przykładowo wskazywano, że taki charakter ma kwestia odpowiedzialności za wydatki i straty związane z przygotowaniem małżeństwa oraz zwrot podarków zaręczynowych. Fragmentaryczność projektowanych regulacji miała więc uzasadniać umieszczenie ich w ostatnim rozdziale. Oceniając przyjęte rozwiązanie, należy zauważyć, że jest ono przejawem postępującej deregulacji instytucji zaręczyn w prawie pozytywnym. Widać w nim niekonsekwencję, gdyż nie zdecydowano się na usunięcie tych przepisów. W tym miejscu należy przypomnieć, że już w trakcie prac nad dekretem unifikacyjnym

${ }^{29}$ S. Szer, op. cit., s. 4.

${ }^{30}$ L. Domański, Uwagi do projektu prawa małżeńskiego osobowego, „Przegląd Notarialny” 1948, t. 2, z. 11-12, s. 383. 
rozważano eliminację tych norm, do czego ostatecznie nie doszło ${ }^{31}$. Skoro przepisy o zaręczynach zachowano, nawet w szczątkowej formie, to bardziej właściwe wydawało się umieszczenie ich na początku tytułu o małżeństwie. Podobny pogląd wyrażono w dyskusji nad projektem ${ }^{32}$. Warto także zaznaczyć, że zastosowane rozwiązanie odbiegało od uregulowań zawartych we współczesnych projektowi kodeksach.

Referent projektu J. Witecki dążył do rozbudowania przepisów o zaręczynach w oparciu o projekt przedwojenny, ale nie uzyskał poparcia żadnego z członków komisji ${ }^{33}$. Instytucja zaręczyn pozostała wobec tego praktycznie niezmieniona w stosunku do rozwiązań dekretowych. Jedynie niewielką modyfikacją było dodanie przesłanki winy jako powodu zerwania zaręczyn. W zaproponowanej regulacji narzeczony, który z winy swej dał słuszny powód do zerwania zaręczyn, miał odpowiadać względem narzeczonego lub jego rodziców za wydatki i straty poniesione wskutek przygotowań do małżeństwa (art. 200). Konsekwencją tego uregulowania było dodanie zastrzeżenia, pozbawiającego narzeczonego prawa żądania zwrotu podarków zaręczynowych, jeżeli z winy swej dał on słuszny powód do zerwania zaręczyn. Ponadto doprecyzowano, że żądanie zwrotu podarków zaręczynowych ma być oparte na przepisach o niesłusznym zbogaceniu $^{34}$ (bezpodstawnym wzbogaceniu według dzisiejszej terminologii).

Przepisy dotyczące zawarcia małżeństwa zostały skonstruowane w sposób odmienny od uregulowań obowiązującego dekretu. Projekt zaniechał bowiem syntetycznego podawania $\mathrm{w}$ jednej normie wszystkich przesłanek ważności zawarcia małżeństwa. Uznano, że recypowanie tego przepisu z dekretu jest zbędne z uwagi na to, że inne przepisy precyzują poszczególne przesłanki ważności, wobec czego nie ma potrzeby ich powtarzać. Nie zamieszczono w związku z tym normy stanowiącej, że małżeństwo jest związkiem osób różnej płci ${ }^{35}$. Ponadto projekt inaczej rozwiązał kwestię granicy wieku uprawniającego do wstąpienia w związek małżeński. Przyjęto, że nie może zawrzeć małżeństwa osoba małoletnia, jednakże $\mathrm{z}$ ważnych powodów sąd mógł zezwolić na zawarcie małżeństwa małoletniemu, który ukończył 15 lat (art. 135). Zmiana w stosunku do obowiązującej regulacji polegała na wyznaczeniu dolnej granicy wieku upoważniającej do wystąpienia

${ }^{31}$ S. Szer był wówczas zwolennikiem pozostawienia w dekrecie przepisów o zaręczynach. Zob. S. Szer, Zaręczyny (rozdział I prawa małżeńskiego), „Demokratyczny Przegląd Prawniczy” 1946, nr 1, s. 14-15, a także P. Fiedorczyk, $Z$ prac nad unifikacja osobowego prawa malżeńskiego $w 1945$ roku, „Miscellanea historico-huridica” 2003, t. 1, s. 77.

${ }^{32}$ L. Domański, op. cit., s. 383.

${ }^{33}$ Protokół posiedzenia Komisji Kodyfikacyjnej Prawa Cywilnego w dn. 20 II 1948 r., AAN MS 2380, k. $18-22$.

${ }^{34}$ S. Szer, Projekt kodeksu cywilnego. Małżeństwo, cz. 2, „Demokratyczny Przegląd Prawniczy” 1948, nr 7, s. 16.

${ }^{35}$ Brak tego rozwiązania skrytykował L. Domański, op. cit., s. 384. 
do sądu z wnioskiem o zezwolenie. Uznano, że małżeństwo z osobą młodszą niż piętnastoletnia rodzi poważne zastrzeżenia natury obyczajowej. Powoływano się przy tym na normę art. 203 k.k., wyznaczającego tę samą granicę przy sankcji karnej za czyn nierządny $\mathrm{z}$ małoletnim ${ }^{36}$. Tak nisko wyznaczona granica wieku spotkała się z krytyką profesora Józefa Górskiego z Poznania, który w przesłanej opinii proponował, by jedynie kobieta, i to po ukończeniu 16. roku życia, mogła wystąpić do sądu o zgodę na zawarcie małżeństwa ${ }^{37}$. Zmianą o mniejszym znaczeniu był umieszczony w projekcie nakaz wymieniania nazwiska małżonka małoletniego w zezwoleniu, gdyż dotychczasowe prawo nie wyłączało generalnych zezwoleń.

Projekt nie regulował zagadnienia zdolności do zawarcia małżeństwa przez osoby ubezwłasnowolnione. Nieumieszczenie tych przepisów w prawie małżeńskim tłumaczono tym, że byłaby ona zbędna wobec projektowanych przepisów części ogólnej kodeksu (art. 79, 81). Twierdzono, że skoro ubezwłasnowolniony całkowicie nie może w ogóle dokonywać czynności prawnych, nie będzie mógł zawrzeć małżeństwa. Natomiast ubezwłasnowolniony częściowo został $\mathrm{w}$ projekcie pozbawiony jedynie prawa do dokonywania czynności o charakterze majątkowym, wobec czego posiadał zdolność do zawarcia małżeństwa ${ }^{38}$. Brak odnośnych regulacji został przekonująco oceniony negatywnie przez doktrynę $e^{39}$.

Znacznie ważniejszą modyfikacją był wprowadzony w projekcie konsekwentny podział przeszkód do zawarcia małżeństwa na przeszkody skuteczne erga omnes oraz względne, czyli skuteczne między stronami. Przeszkody względne zostały zredagowane $\mathrm{w}$ ten sposób, że w dyspozycji normy użyty jest zwrot „ze sobą” (np. art. 140: „Nie wolno zawrzeć ze sobą małżeństwa osobom pozostającym $\mathrm{w}$ stosunku przysposobienia, dopóki ten stosunek nie ustanie"), natomiast w przypadku przeszkód bezwzględnych zwrot ten został opuszczony (np. art. 136). Projekt wprowadzał ponadto istotne zmiany w podziale przeszkód małżeńskich na zrywające (dirimentia) oraz tamujące (impedimentia). Inaczej niż prawo obowiązujące, projekt zaliczył gruźlicę i chorobę weneryczną $\mathrm{w}$ stanie zaraźliwym oraz stosunek przysposobienia do przeszkód tamujących. Twórcy projektu uznali, że ingerencja państwa $\mathrm{w}$ stosunki między małżonkami nie powinna sięgać w tych przypadkach aż tak

\footnotetext{
${ }^{36}$ S. Szer, op. cit., cz. 1, s. 4.

${ }^{37}$ Prof. dr Józef Górski. Uwagi o projekcie prawa osobowego i prawa majątkowego małżeńskiego, AAN MS 2230, k. niepaginowana.

${ }^{38}$ Ibidem, s. 4.

39 „Nie jest chyba rzeczą społecznie pożądaną, aby mogły wstępować w związki małżeńskie osoby ubezwłasnowolnione częściowo z powodu choroby psychicznej lub niedorozwoju psychicznego" - pisał J. Gwiazdomorski, Zawarcie małżeństwa, „Państwo i Prawo” 1949, nr 4, s. 50-52.
} 
daleko, by doprowadzać do unieważnienia małżeństwa. Podkreślano natomiast, że projekt wymieniał chorobę weneryczną jako jedną z przesłanek rozwodu (art. 183 pkt 4 projektu). Zaproponowane zmiany oznaczały więc zmniejszenie liczby przeszkód zrywających, co w praktyce skutkowało mniejszą ingerencją państwa w życie małżeńskie.

Proponowane zmiany merytoryczne $\mathrm{w}$ zakresie przeszkód zrywających i tamujących połączono $\mathrm{z}$ nową redakcją przepisów. Przy przeszkodach zrywających projekt używał zwrotów „nie może” lub „nie mogą” zawrzeć małżeństwa, zaś przy przeszkodach tamujących - „nie wolno”. Tego rodzaju redakcja zmierzała do zapewnienia przejrzystości układu tekstu.

Projekt, podobnie jak obowiązujące wówczas prawo małżeńskie, podkreślał wyraźnie świecki charakter instytucji małżeństwa. „Sprawa świeckiej formy małżeństwa musi być wyraźnie postawiona. Czynią to nawet konstytucje wielu państw, jak Jugosławii, Bułgarii, Albanii i innych" - stwierdzał imperatywnie min. H. Świątkowski w trakcie prac nad pierwszym czytaniem ${ }^{40}$. Nalegał także, by $\mathrm{w}$ kodeksie znalazł się przepis mówiący o uroczystej formie aktu ślubu. $\mathrm{W}$ związku ze stanowiskiem wyrażonym przez ministra umieszczono w art. 148 projektu odpowiednią normę (była to nowość w stosunku do obowiązującego prawa) o publicznej i uroczystej ceremonii przed urzędnikiem stanu cywilnego. Inne proponowane zmiany miały polegać na dodaniu przepisu art. $141 \$ 2$, który stwierdzał, że „związek, który nie został zawarty przed urzędnikiem stanu cywilnego, nie jest małżeństwem w rozumieniu ustawy". Przepis ten nie zmieniał istniejącego stanu prawnego, gdyż, mimo braku wyraźnej normy, był identyczny. Umieszczenie tej regulacji miało ugruntować w społeczeństwie świadomość, iż śluby kościelne nie wywołują skutków prawnych. Doświadczenia obowiązywania dekretu małżeńskiego były bardzo złe, gdyż w 1946 r. około 60\% ślubów nie zawierano przed urzędnikiem stanu cywilnego ${ }^{41}$.

Większe znaczenie $\mathrm{w}$ procesie utrwalania świeckiej formy małżeństwa należy przypisać projektowanemu art. 198, w myśl którego osobom, które nie zawarły małżeństwa według powołanych przepisów kodeksu, nie wolno zawierać małżeństwa wyznaniowego. Przepis ten został wprowadzony na polecenie min. H. Świątkowskiego, który uważał go za konieczny ${ }^{42}$. Projektodawcy wyjaśniali,

${ }^{40}$ Protokót posiedzenia Komisji Kodyfikacyjnej Prawa Cywilnego w dniu 17 II 1948 r., AAN MS 2380, k. 8 .

${ }^{41}$ Szerzej na ten temat: P. Fiedorczyk, Unifikacja i kodyfikacja prawa rodzinnego na tle stosunków pomiędzy państwem a Kościołem katolickim w Polsce, [w:] Cuius regio, eius religio?, G. Górski, L. Ćwikła, M. Lipska (red.), Lublin 2006, s. 423.

${ }^{42}$ Protokół posiedzenia Komisji Kodyfikacyjnej Prawa Cywilnego w dn. 23 II 1948 r., AAN MS 2380, k. 37. 
że podobne regulacje są stosowane $\mathrm{w}$ ustawodawstwach europejskich, np. w szwajcarskim oraz niemieckim. Ratio legis tego przepisu wyrażało się w dążeniu do zapobieżenia ujemnym skutkom nierejestrowania małżeństwa, wśród których wymieniano faktyczną bigamię, nieistnienie obowiązku alimentacyjnego, praw do spadku oraz traktowanie dzieci jako pozamałżeńskich ${ }^{43}$. Jest rzeczą interesującą, że proponowana regulacja spotkała się z uznaniem wyrażonym przez Ludwika Domańskiego, który pisał: „Taka dwulicowość małżeństwa sprzeciwia się porządkowi publicznemu i winna być zabroniona" ${ }^{44}$. Warto odnotować, że przed wojną Domański był jednym z najbardziej nieprzejednanych krytyków znacznie mniej radykalnego projektu Karola Lutostańskiego ${ }^{45}$. Niemożliwe jest dzisiaj ustalenie, co było przyczyną tak radykalnej zmiany poglądów tego wybitnego prawnika.

W tym miejscu warto zauważyć, że członkowie komisji zastanawiali się, w jakim akcie prawnym umieścić sankcję karną wobec duchownego, który udzielał ślubu przed dopełnieniem świeckiego aktu zawarcia małżeństwa. Proponowano, by umieścić ją bądź w przepisach wprowadzających kodeks cywilny, bądź w prawie o aktach stanu cywilnego. Jan Wasilkowski wskazywał, że najbardziej właściwym miejscem, wzorem prawa francuskiego, byłby kodeks karny. Kwestii tej jednak nie rozstrzygnięto ${ }^{46}$.

Ważną modyfikacją przepisów o formie zawarcia małżeństwa było umieszczenie $\mathrm{w}$ projekcie przepisów nakazujących każdemu, komu wiadoma była przeszkoda do zawarcia małżeństwa, doniesienia o niej urzędnikowi stanu cywilnego. Urzędnik miał wówczas zwrócić się do sądu o rozstrzygnięcie, czy małżeństwo może być zawarte (art. 146-147). Projektowane przepisy były więc świeckim odpowiednikiem zapowiedzi, podkreślano przy tym, że podobne uregulowania funkcjonują $\mathrm{w} \mathrm{ZSRR}^{47}$. Projekt jednak generalnie zmierzał do uproszczenia przesłanek formalnych do zawarcia małżeństwa, „aby nie stwarzać zbytnich trudności w zawieraniu małżeństw i aby w przypadkach, gdy przesłanki te decydują o ważności, nie stwarzać zbyt szerokiej podstawy do unieważnienia"48. Uproszczenie przepisów o formie miało polegać na niedopuszczalności unieważnienia małżeństwa z powodu małoletniości świadków.

${ }^{43}$ S. Szer, op. cit., cz. 1, s. 15.

${ }^{44}$ L. Domański, op. cit., s. 411.

${ }^{45}$ L. Domański, O małżeństwie. Studium społeczno-prawne, omawiające kwestie małżeństw religijnych i cywilnych oraz rozwodów, Warszawa 1932; idem, Odpowiedź na uwagi prof. Lutostańskiego z powodu pracy L. Domańskiego „O malżeństwie”, Warszawa 1932.

${ }^{46}$ Protokót posiedzenia Komisji Kodyfikacyjnej Prawa Cywilnego w dn. 25 II 1948 r., AAN MS 2380, k. 53.

${ }^{47}$ S. Szer, op. cit., s. 6.

${ }^{48}$ Ibidem. 
W przepisach o unieważnieniu małżeństwa projekt podkreślał istotę unieważnienia,wyróżniającąjąodrozwodu.Zgodniezart.167 projektumałżeństwo unieważnione uważane miało być za niezawarte, o ile co do poszczególnych skutków ustawa inaczej nie stanowiła. Wyjątki co do zasady, iż unieważnienie wywiera skutki ex tunc, dotyczyły trzech sytuacji. Dziecko z małżeństwa unieważnionego uznawano za dziecko z małżeństwa (art. 168). Ponadto przepisy o stosunku rozwiedzionych małżonków do ich wspólnego dziecka oraz przepisy o stosunkach majątkowych pomiędzy rozwiedzionymi małżonkami miały być stosowane odpowiednio do unieważnienia małżeństwa. Obie te sytuacje były uregulowane w obowiązującym dekrecie, natomiast projekt dodawał do nich jeszcze jedną. Zgodnie $\mathrm{z}$ art. 170 przepisy o wzajemnych obowiązkach małżonków i ich stosunku do dzieci w czasie procesu o rozwód miały być stosowane odpowiednio do unieważnienia małżeństwa. Powyższe wyjątki, jak podkreślano, nie czynią zbędnej samej zasady ani nie pozbawiają jej praktycznego znaczenia. W razie unieważnienia małżeństwa sąd nie mógł bowiem zezwolić żonie na zachowanie nazwiska męża. Ponadto małoletni, który przez zawarcie związku małżeńskiego stawał się pełnoletni, w razie unieważnienia powracał do stanu małoletniości ${ }^{49}$.

Projekt utrzymywał dotychczasowy stan prawny, w myśl którego o unieważnieniu orzekał sąd (art. 154). Nie rozróżniał on natomiast powództw o unieważnienie w zależności od charakteru przeszkody lub osoby uprawnionej do wniesienia powództwa.

W projekcie można zaobserwować tendencję do zawężenia przyczyn unieważnienia, co w praktyce oznaczało dążenie do utrzymania zawartych małżeństw. Wspomniano już wyżej o ograniczeniach unieważnienia w przypadku niezachowania formy zawarcia związku. Innym przykładem może być projektowany art. $161 \$ 2$, który wyłączał błąd co do istotnych właściwości fizycznych lub moralnych drugiego małżonka jako podstawę do żądania unieważnienia. Pozostawiono jedynie, na wniosek J. Wasilkowskiego ${ }^{50}$, błąd co do tożsamości osoby. Ponadto projekt wyraźnie formułował zasadę, dotychczas tylko wynikającą z obowiązującego dekretu, iż nie można żądać unieważnienia małżeństwa po jego ustaniu (art. $163 \$ 1$ ). Ważną modyfikacją było uzupełnienie dotychczasowej regulacji poprzez postanowienie, iż w razie przeszkody bigamii lub pokrewieństwa taka możliwość została zachowana. W tym przypadku rozszerzono krąg osób uprawnionych do żądania unieważnienia. Miał on obejmować pro-

\footnotetext{
${ }^{49}$ Innego zdania był referent projektu J. Witecki, Prawo małżeńskie i przepisy wprowadzające prawo małżeńskie z komentarzem, Łódź 1946, s. 33.

${ }^{50}$ Protokót posiedzenia Komisji Kodyfikacyjnej Prawa Cywilnego z dn. 21 II 1948 r., AAN MS 2380, k. 31 .
} 
kuratora, któregokolwiek z małżonków oraz (co było nowością) osobę mającą w tym interes prawny (art. 154). Obie zmiany uzasadniano koniecznością likwidacji patologicznych sytuacji, mogących trwać nadal nawet po śmierci jednego z małżonków ${ }^{51}$.

Mniej istotna modyfikacja została zawarta w art. 166 projektu. Stanowił on, że w wyroku orzekającym unieważnienie sąd orzekał także, czy i który z małżonków zawarł małżeństwo w złej wierze. Obowiązujący dekret natomiast nakazywał sądowi ustalać dobrą wiarę. Proponowana zmiana wynikała z art. 7 części ogólnej projektu, który mówił o domniemaniu dobrej wiary - tej więc nie trzeba było ustalać.

Rozdział III prawa małżeńskiego, zawierający przepisy dotyczące praw i obowiązków małżonków, został znacznie powiększony $\mathrm{w}$ porównaniu z uregulowaniami zawartymi w obowiązującym dekrecie. Wynikało to, o czym wspomniano wyżej, z umieszczenia w nim także unormowań dotyczących stosunków majątkowych między małżonkami - w związku z nową systematyką. Najważniejszą merytoryczną modyfikacją była propozycja uregulowania tzw. separacji faktycznych. Według art. 173 projektu w razie ustania wspólnego pożycia z winy jednego z małżonków, drugi z małżonków mógł żądać zasądzenia renty, która miała odpowiadać wysokości udziału winnego małżonka w kosztach utrzymania drugiego małżonka i wspólnych niepełnoletnich dzieci. Brak takiej regulacji $\mathrm{w}$ obowiązującym dekrecie wynikał $\mathrm{z}$ programowego odrzucenia instytucji prawnej separacji małżonków. Jednak nawet krótki okres obowiązywania dekretu unaocznił, iż pominięcie tego problemu wywoływało negatywne skutki społeczne ${ }^{52}$. Twórcy projektu uznali więc, że „ustawodawca nie może zamykać oczu na problem tzw. separacji faktycznych, jeżeli idzie o ich wpływ na stosunki alimentarne małżonków"53. Wobec powyższego nie zaproponowali regulacji prawnej instytucji separacji, ograniczając się jedynie do fragmentarycznej regulacji kwestii majątkowych z niej wynikających. Przesłanką żądania renty miało być ustanie wspólnego pożycia, wywołane winą małżonka, zobowiązanego do ponoszenia kosztów utrzymania współmałżonka i nieletnich dzieci. Taka redakcja przepisu wyłączała powstanie obowiązku alimentacyjnego w przypadku separacji opartej na porozumieniu małżonków. Warto zwrócić uwagę, że tak określony obowiązek alimentacyjny różnił się od tego, który wynikał z orzeczenia rozwodu. W szczególności nie uzależniono powstania obowiązku alimentacyjnego od konieczności wykazania niemożności utrzymywania się

${ }^{51}$ S. Szer, op. cit., s. 7.

${ }^{52} \mathrm{~A}$. Wolter, Wzajemne obowiązki małżonków wypadku ustania wspólnego pożycia, „Demokratyczny Przegląd Prawniczy" 1947, nr 5, s. 19-27.

${ }^{53}$ S. Szer, op. cit., cz. 2, s. 10. 
własnymi siłami oraz od stanu majątkowego i rodzinnego drugiego małżonka (art. 195 projektu). Takie rozwiązanie miało ułatwić uzyskanie alimentów.

Kolejna modyfikacja wynikała $\mathrm{z}$ art. 176 projektu, według którego $\mathrm{w}$ braku porozumienia pomiędzy małżonkami $\mathrm{w}$ istotnych sprawach wspólnego gospodarstwa lub wychowania dzieci, każdy z nich może zwrócić się o rozstrzygnięcie do sądu. Intencją twórców projektu było przeciwdziałanie rozwodom, a ponadto propozycja ta zwiększała rolę sądu (co oznaczało wzrost ingerencji państwa w stosunki małżeńskie).

Istotnym doprecyzowaniem obowiązującego stanu prawnego było uzupełnienie zawarte $\mathrm{w}$ art. $175 \$ 2$ projektu. Według niego dokonane przez sąd pozbawienie lub ograniczenie $\mathrm{w}$ prawie do zaciągania zobowiązań przez jednego z małżonków w zwykłych sprawach gospodarstwa i wychowania dzieci miało być skuteczne wobec osób trzecich tylko wtedy, gdy one o tym wiedziały. Rozwiązanie to było uzupełnieniem poważnej luki w prawie, która powodowała zachwianie pewności obrotu. Konsekwencją proponowanej regulacji miał być obowiązek informowania wierzycieli o ograniczeniu w zdolności do czynności prawnych w stosunku do jednego z małżonków. Tylko wtedy drugi z nich mógł się uchylić od solidarnej odpowiedzialności za zobowiązania zaciągnięte przez małżonka, wobec którego sąd orzekł o pozbawieniu lub ograniczeniu w prawie do zaciągania zobowiązań.

Najbardziej obszerne zmiany zostały zaproponowane w układzie i treści przepisów o rozwodzie. Wynikało to $\mathrm{z}$ faktu, iż dotychczasowa regulacja instytucji rozwodu w dekrecie małżeńskim nie była dostatecznie przejrzysta i wywoływała rozbieżności w orzecznictwie ${ }^{54}$.

Twórcą projektu nowych przepisów rozwodowych był J. Wasilkowski, który zgłosił je jako wniosek odrębny wobec propozycji J. Witeckiego i S. Szera. Projekt Wasilkowskiego uzyskał poparcie min. H. Świątkowskiego, co spowodowało, że stał się on podstawą dalszych prac ${ }^{55}$. Konstrukcja projektu opierała się na tych samych przesłankach, jakie wynikały $\mathrm{z}$ regulacji zawartych $\mathrm{w}$ obowiązującym dekrecie. Zgodnie $\mathrm{z}$ art. 183 projektu sąd orzekał rozwód, jeżeli stwierdził, że nastąpił trwały i zupełny rozkład pożycia, spowodowany jedną z pięciu wymienionych w tym artykule przyczyn. Ponadto sąd miał obowiązek ustalić, że przyczyny te nie zostały wywołane przez tego z małżonków, który wystąpił $\mathrm{z}$ żądaniem rozwodu. Konieczne było także ustalenie przesłanki negatywnej - zgodnie z art. 186 rozwód nie był dopuszczalny, jeżeli sprzeciwiał się dobru małoletnich dzieci obojga małżonków.

${ }^{54}$ Szerzej na ten temat: P. Fiedorczyk, Rozwód w zunifikowanym prawie małżeńskim z 1945 r. Geneza, konstrukcja, orzecznictwo, „Miscellanea historio-iuridica” 2004, t. 2, s. 102-106.

${ }^{55}$ Protokół posiedzenia Komisji Kodyfikacyjnej Prawa Cywilnego w dn. 23 II 1948 r., AAN MS 2380, k. 36-39. 
Utrzymanie dotychczasowych generalnych rozwiązań łączyło się jednak z propozycjami poważnych zmian. Projekt, inaczej niż dekret, wymieniał przyczyny wyczerpująco (zrezygnowano ze zwrotu „w szczególności”), jednak zamiast jedenastu przyczyn, ograniczył je do pięciu. Zmiana ta nie oznaczała jednak faktycznie ograniczenia liczby przyczyn rozwodowych, skoro w projekcie znalazła się przyczyna w postaci „rażącego naruszenia obowiązków wynikających z małżeństwa" (art. 183 pkt 1). W intencji twórców projektu miała ona obejmować szereg przyczyn „klasycznych”, dotychczas wymienianych w dekrecie. Elastyczność proponowanej formuły miała powodować, że ten sam fakt, zależnie od okoliczności, mógł być uznany lub nie uznany przez sąd za przyczynę rozkładu ${ }^{56}$. Pozostałe wymienione $\mathrm{w}$ art. 183 przyczyny (popełnienie czynu hańbiącego lub uprawnianie takiego zajęcia, choroba psychiczna trwająca od co najmniej trzech lat $t^{57}$, choroba weneryczna niebezpieczna dla małżonka lub potomstwa, niemoc płciowa do 50. roku życia oraz skazanie na karę więzienia od pięciu lat) stanowiły przeszkodę w normalnym współżyciu małżonków i mogły wywołać zupełny i trwały rozkład pożycia. Wśród tych przyczyn nową było skazanie na karę więzienia ${ }^{58}$.

Projektowane ujęcie przepisów wyłączało wykładnię, istniejącą na podstawie przepisów dekretu, według której przyczyny rozwodowe mogły powodować orzeczenie rozwodu bez konieczności wykazywania rozkładu współżycia. Nowa redakcja nie pozostawiała wątpliwości, że przesłanka rozkładu współżycia musiała występować razem z jedną z przyczyn wymienionych w art. 183.

Projekt zmieniał „stały” na „trwały” rozkład pożycia, wychodząc z założenia, że wyrażenie „stały” kładło zbytni nacisk na zmianę czasu ${ }^{59}$. Powrócono tym samym do przedwojennej propozycji K. Lutostańskiego i uwzględniono krytyczną opinię komentatora dekretu ${ }^{60}$.

Bardzo ważną zmianą zaproponowaną $\mathrm{w}$ projekcie (prawdopodobnie najważniejszą) była przewidziana w art. 185 możliwość uzyskania rozwodu, jeżeli małżonkowie żyli co najmniej od pięciu lat w całkowitym rozłączeniu, a okoliczności wyłączały prawdopodobieństwo, że pożycie małżonków zostanie przywrócone. $\mathrm{Z}$ żądaniem rozwodu nie mógł jednak wystąpić małżonek ponoszący wyłączną winę rozłączenia (zasada rekryminacji), chyba że drugi

${ }^{56}$ S. Szer, op. cit, s. 12.

${ }^{57}$ Trzyletni okres choroby psychicznej był zmianą w stosunku uregulowania dekretowego, które uprawniało do wystąpienia o rozwód już po roku trwania choroby psychicznej (art. 24 pkt 10 dekretu).

${ }^{58}$ Nowa w tym sensie, że nie przewidywał jej obowiązujący dekret. Natomiast wymieniał ją np. projekt K. Lutostańskiego oraz pierwsze projekty dekretu małżeńskiego. Zob. P. Fiedorczyk, Rozwód, op. cit., s. 97-102.

${ }^{59}$ S. Szer, op. cit., s. 12.

${ }^{60}$ J. Gwiazdomorski, Nowe prawo małżeńskie, Kraków 1946, s. 24. 
małżonek odmawiał powrotu do wspólnego pożycia, a przyczyna rozłączenia ustała. Również w tym przypadku konieczne było spełnienie przesłanki negatywnej $\mathrm{w}$ postaci dobra niepełnoletnich dzieci. Projektowana regulacja ułatwiała więc możliwość uzyskania rozwodu po minimum pięcioletniej separacji faktycznej, przy czym nie wykluczała ona rozwodu, jeżeli żaden z małżonków nie ponosił winy rozkładu pożycia. Przyjmując zasadę rekryminacji uznano jednak, że do społecznie niepożądanych skutków prowadzi utrzymywanie małżeństw faktycznie nieistniejących. Dlatego wyłączono jej stosowanie w sytuacji, gdy małżonek niewinny rozkładu odmawiał powrotu do wspólnego pożycia. Tak ukształtowane przepisy umożliwiały w praktyce rozwód na zgodny wniosek stron po upływie pięcioletniego okresu separacji.

Sytuacja prawna dziecka $\mathrm{w}$ razie orzeczenia rozwodu została $\mathrm{w}$ projekcie częściowo zmieniona w stosunku do obowiązującego prawa. Projekt stanowił w art. 190, że dobro dziecka oraz interes społeczny miały decydować o tym, któremu z rodziców przyznać prawo wykonywania władzy rodzicielskiej. Pominięto zawarte $\mathrm{w}$ dekrecie prawo pierwszeństwa $\mathrm{w}$ tym względzie, przysługujące niewinnemu małżonkowi. Ponadto przewidziano (art. 191 projektu) możliwość pozbawienia władzy rodzicielskiej jednego lub obojga rodziców. Przypuszczać należy, że w przypadku pozbawienia władzy rodzicielskiej sąd działałby z urzędu, co zwiększało ingerencję państwa w stosunki rodzinne.

Projekt ponadto inaczej niż dekret określał uprawnienie rozwiedzionej małżonki do nazwiska męża, zezwalając na jego zachowanie lub na dołączenie do własnego nazwiska.

Przepisy o roszczeniach majątkowych wynikających z rozwodu zostały zmienione w niewielkim stopniu w stosunku do obowiązującego prawa. W szczególności niezmienione pozostały regulacje dotyczące obowiązku alimentacyjnego. Utrzymano także zasadę, według której niewinny małżonek może żądać naprawienia szkody poniesionej wskutek rozwodu, a także wyrządzonej czynem, który był podstawą rozwodu (art. 194). Pominięto jednak prawo żądania naprawienia szkody za utratę korzyści, wynikających z małżeńskiej umowy majątkowej. Uznano bowiem, że zagadnienie to zostanie uregulowane w przepisach o umownych małżeńskich ustrojach majątkowych. Pozostawiono natomiast prawo żądania zadośćuczynienia za krzywdę moralną. Ważnym doprecyzowaniem było ograniczenie czasowe tych roszczeń tylko do postępowania rozwodowego (art. $194 \$ 2$ projektu).

Ocena projektowanych rozwiązań kodeksu cywilnego w zakresie osobowego prawa małżeńskiego powinna łączyć się z odpowiedzią na pytanie o stopień uwzględnienia założeń, będących podstawą prac nad kodyfikacją. Przypomnijmy, że kodeks miał być opracowany na bazie dekretów unifikacyjnych, a zadania komisji ograniczać się miały w zasadzie do działań o charakterze porządkującym, technicznym, kompilacyjnym. Zmiany merytoryczne miały być wprowadzane 
tylko wtedy, gdy było to konieczne. Przyjąć należy, że w zakresie prawa małżeńskiego projekt, opierając się wprawdzie na dekretach: prawo małżeńskie z 1945 r. i prawo małżeńskie majątkowe z 1946 r., wykraczał daleko poza zamierzone na wstępie zmiany techniczne. Uzasadnieniem takiego poglądu są przede wszystkim regulacje dotyczące skutków prawnych faktycznej separacji w postaci prawa żądania alimentów oraz - co szczególnie zwraca uwagę - prawa wystąpienia z powództwem o rozwód. W ten sposób separacja, usunięta z systemu polskiego prawa w $1945 \mathrm{r}$. z powodów ideologicznych (antykościelnych), została fragmentarycznie przywrócona w projekcie kodeksu. Proponowane nowe ujęcie przepisów rozwodowych zart. 185, skutkujące możliwością uzyskania rozwodu po pięcioletniej separacji, bez konieczności wykazywania winy, oznaczało poważne osłabienie zasady trwałości małżeństwa. Umieszczenie takiej regulacji wydaje się jednak celowe, gdyż utrzymywanie faktycznie nieistniejących małżeństw nie było społecznie uzasadnione. Pamiętać ponadto należy, że w trakcie prac nad projektem kodeksu nadal obowiązywał art. XIII przepisów wprowadzających prawo małżeńskie, który zezwalał małżonkom na rozwód na zgodny wniosek stron, jeżeli małżeństwo trwało dłużej niż trzy lata. Wprawdzie był to przepis o charakterze temporalnym (obowiązywał do końca 1948 r.), ale jego skutki sięgały znacznie dalej niż projektowana regulacja. W związku z tym uzasadnione wydaje się stwierdzenie, że rozwód z art. 185 miał w intencji projektodawców wypełnić przyszłą lukę, jaka mogła powstać po wygaśnięciu obowiązywania art. XIII. Paradoksalnie w tym kontekście zasada trwałości małżeństwa ulegała wzmocnieniu, a nie osłabieniu.

Zasada trwałości została także wzmocniona poprzez nową redakcję przepisów o unieważnieniu małżeństwa. Cel ten osiągnięto poprzez eliminację lub zmianę charakteru prawnego niektórych przesłanek unieważnienia (gruźlica, choroba weneryczna, błąd co do właściwości małżonka).

Można ponadto zastanawiać się, czy jedynie porządkujący charakter miały zmiany w podstawowej konstrukcji rozwodu (art. 183 projektu na tle art. 24 dekretu). Projekt, w przeciwieństwie do dekretu, wprowadzał bowiem zamknięty katalog przyczyn rozwodowych. Na podkreślenie zasługuje jednak przyczyna w postaci „rażącego naruszenia obowiązków wynikających z małżeństwa” na tyle elastyczna, że mogła obejmować wiele stanów faktycznych. Jej wpływ na obowiązywanie zasady trwałości małżeństwa mógł być oceniony tylko na podstawie orzecznictwa sądowego, do czego, jak wiemy, nie doszło.

Zdecydowanie porządkujący (ale także merytoryczny) charakter miało wprowadzenie przepisu zakazującego zawierania małżeństw wyznaniowych przed dopełnieniem ceremonii w urzędzie stanu cywilnego. Brak tego rozwiązania doprowadził do negatywnych skutków społecznych, istniejących do dziś.

Zaproponowana przez twórców projektu systematyka przepisów była przejrzysta. Odejście od niemieckiego modelu majątkowego prawa małżeńskiego 
na rzecz konstrukcji o francuskim i szwajcarskim rodowodzie było zmianą techniczną, a nie merytoryczną i nie wywoływało kontrowersji. Te z kolei dotyczyły wspomnianego wyżej umieszczenia przepisów o zaręczynach na końcu tytułu.

Warto także zwrócić uwagę na fakt wyłaniający się z lektury protokołów posiedzeń komisji. Otóż twórcy projektu odwoływali się wielokrotnie do rozwiązań zawartych w niemieckim, szwajcarskim i francuskim kodeksie cywilnym. Ponadto stale mieli na uwadze rozwiązania projektu K. Lutostańskiego, co jest zrozumiałe, skoro dominujący w pracach komisji J. Wasilkowski był członkiem przedwojennej Komisji Kodyfikacyjnej. Nigdy zaś nie zauważano prawa radzieckiego, a zawarte w publikacjach wzmianki o tym prawie miały charakter „ozdobników” tekstu, z których nic dla przyjętych rozwiązań nie wynikało.

Generalnie bardzo pozytywna ocena projektu ${ }^{61}$ nie oznacza, że nie był on pozbawiony wad. Pamiętać jednak należy, że oceniany dokument był tylko i niestety tekstem pierwszego czytania, wobec czego nie można przesądzać ostatecznego kształtu przepisów. Zebrane przez komisję opinie o projekcie pozwalają jednak przypuszczać, iż w toku dalszych prac byłyby on udoskonalony. Dalszy ciąg jednak nie nastąpił, gdyż w ramach postępującej stalinizacji Polski zaniechano prac nad projektem całego kodeksu. Powstały w 1950 r. kodeks rodzinny opierał się już na zupełnie innych założeniach.

${ }^{61}$ Wyraził ją m.in. prof. J. Górski. Zob. Prof. dr Józef Górski, doc. cit. 